\title{
Mutual Influences of New Julfa and Isfahan Mural
Paintings in the $17^{\text {th }}$ Century New Julfa and Isfahan Mural
Paintings in the $17^{\text {th }}$ Century
}

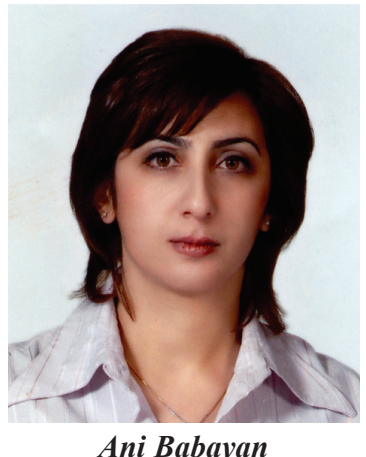

Ani Babayan

$T^{n}$ the $17^{\text {th }}$ century one of the primary reasons of the

transfer of Armenian population from Julfa, Armenia to Isfahan, Iran by Shah Abbas, and the foundation of New Julfa, was to safeguard the artistic wealth of his new capital city of Isfahan. Within a few years, estates, gardens, mosques, schools, bridges and merchant houses were built and industrial establishments were founded. During this time Armenian and Persian artisans and craftsmen appeared on the scene. There were also mural painters who were needed to bring life to the interior decorations of these structures. Each presented an individual distinction and character.

The construction of the historical landmarks mentioned above was achieved due to the notable contributions made by many different layers of the Armenian community of New Julfa. The greatest contribution was made by various Armenian merchant houses. Great was the role of Armenian merchants in introducing different featurs of the European renaissance art styles into the Armenian and Persian communities of Isfahan and New Julfa.

It is noteworthy that in the artistic community of the deported Armenians of Julfa there were also manuscript artisans whose creative activity was connected both with spiritual and secular spheres. They continued their work and established the New Julfa School of Manuscript Art. These artisans were very active in the interior decoration of the Armenian churches in New Julfa.

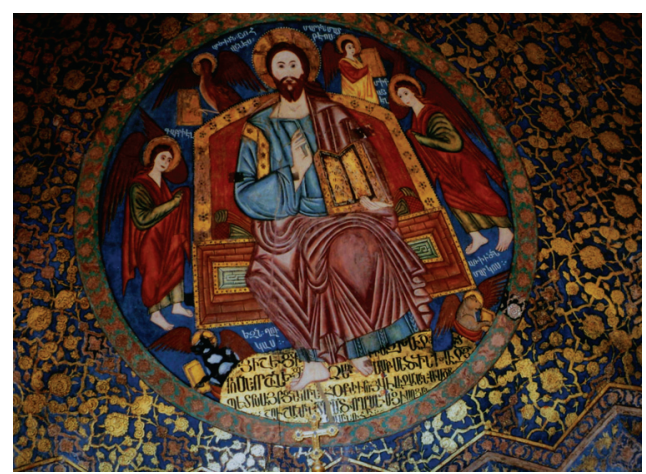

Eastern view, above alter, 17th century St. Betlehem Church, New Julfa 
In the $17^{\text {th }}$ century the typical interior design included mural painting, easel painting and decorative art. In Isfahan the most popular art was based on secular style and presented subjects such as war, parties, and lovers, as well as male or female human figures. In New Julfa religious art also had a strong presence. Themes such as scenes from the Bible or artistic details from the Armenian Apostolic Church sacraments, Christian Saints and church benefactors are noted.

Although mural paintings in Isfahan and New Julfa date back to the same period (1605 -1660), there are differences as well as similarities reflecting the cultural traditions of each community.

Decorative art played an important role in the interior design. It provided a background, as well as a frame or enclosure for paintings. It also created an overall unity and harmony to the overall interior. As a rule decorative arts in Isfahan and New Julfa have a great deal of similarity. One point of interest is the decorative art painted on domes. They provide the viewer a pleasant aesthetic exercise by focusing the eye to the central point and the heavens.

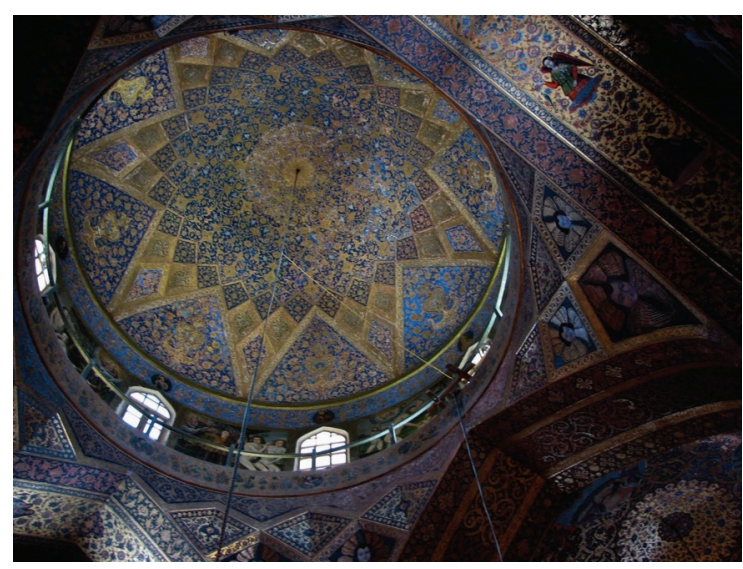

Dome view, 17th century

St. Hovsep Aremantazi (The Vank) Church, New Julfa

Domes in mosques are covered with ceramic tiles arranged so as to reflect botanical or geometric designs, as well as calligraphic texts from the Quran. Since human profile or figure is not permitted in mosques, Islamic art on the whole does not go beyond the reflection of geometric, botanical and calligraphic elements. Among Islamic nations, Persian artists are the only ones who have used human profile or figures. This is due to the very rich Persian literature which dates back to the preIslamic era. Starting from the $7^{\text {th }}$ century (Sassanian Dynasty) to the $16^{\text {th }}$ century (Safavid Dynasty) human profile and figures were omitted in Persian Art presentation. One of the reasons why the Shiia Sect was formalized by Shah Abbas may have been to return classical Persian art back to life. As a result mural paintings started to reappear in all Persian palaces with secular motifs. 
Churches, estates and palaces in New Julfa also had ceramic tile decorations. The primary difference in the mosaic tile work appearing in New Julfa and Isfahan is the color and the theme. The background colors used in New Julfa are based on yellow, which signifies Christianity. In Isfahan mosaic tiles have the dark blue color known as Lagevard which symbolizes the Islamic religion. Another difference in the use of ceramic tile design is the use of human figures in New Julfa and of birds in Isfahan ceramic tiles.
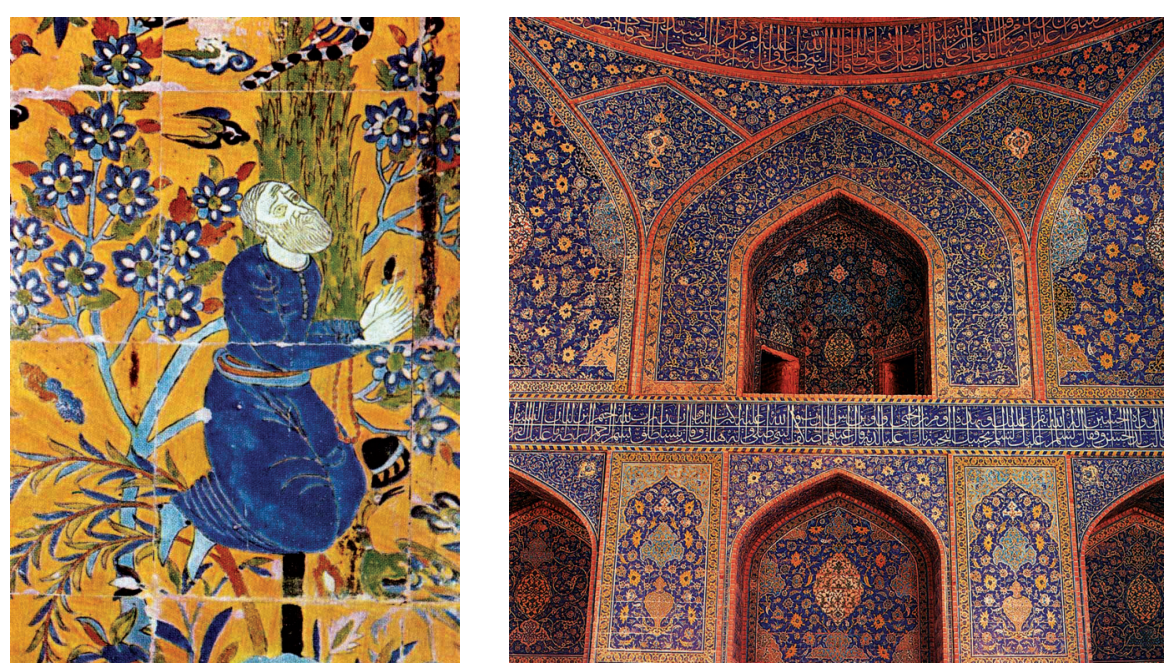

The Armenian Church of St. Hakop constructed in 1607 has the Armenian Khachkar (cross stone) used for interior decoration. After 1613, except for St. Nikoghayos, all Armenian churches have mural paintings. A distinctive interior design covered with mural paintings from the dome down to the walls followed by ceramic tiles on the walls down to the floor distinguishes the churches of St. Betlehem and St. Hovsep Aremantazi (The Vank). All other churches have a simpler dome and interior wall decorations.

When compared, mural paintings reveal technical similarities between Isfahan and New Julfa trends. These similarities display a European influence and have given rise to speculation amongst analysts as to what their source is. One hypothesis is that European painters were employed in the production of these murals. However, the tense religious and social environment of the time, rules this opinion out. It is believed that the European influence is the result of active commercial contacts between European and Armenian merchants and their endeavours to bring the new styles into their culture. It is possible that local artists had a working relationship with European artists who visited Isfahan at that time. There are documents in archives that show evidence of Armenian artists providing Persian artists techniques in design and construction. There were instances when Armenian artists were commissioned to produce their designs in the construction of the new Capital City of Isfahan.

Sometimes there is also evidence of multiple craftsmen in a single composition. For example, a human figure may have noticeable differences in quality in each section. 
There are also paintings that are done in a simple manner but being sincere they manage to establish a direct and instant contact with the viewer.

The majority of mural paintings in Isfahan palaces are based on the traditional Iranian miniature illustrations. It appears as though the scale of the illustration is the only thing that may have changed. In Isfahan and New Julfa such murals can be found in the Armenian St. Bethlehem Church and the Sukazian Estate and the Persian Palaces Chehel Sotoun and Alighapou.

All mural paintings have the primary subject matter located in the most central part of the mural. Most paintings show a tendency to reduce human figures down to only a few relevant characters. In church paintings human figures represent a specific saint or a biblical event. In private estates these murals show human figures, without a specific name or event. In palaces, the mural will show the king with multitudes of his subjects.

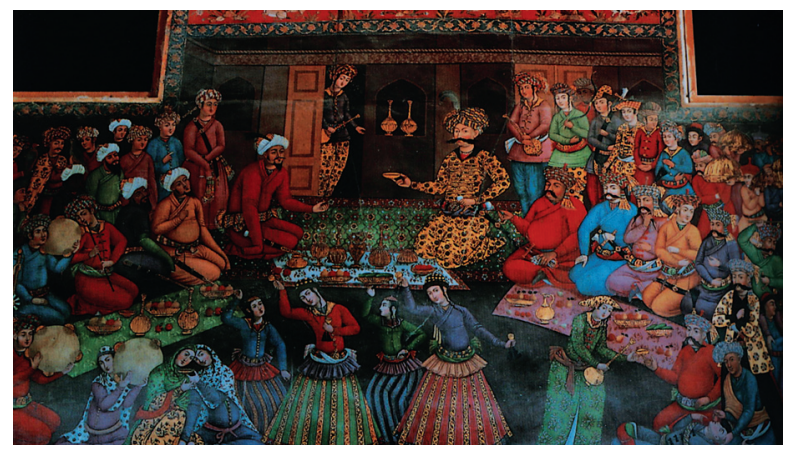

Main Hall, western view, 17th century

Chehel Sotoun Palace, Isfahan

In New Julfa murals which show human profile, the artist seems to have emphasized emotions by use of facial expressions. The characters in these murals tend to be of different ages. The profiles show half, three quarter and full view of the face.

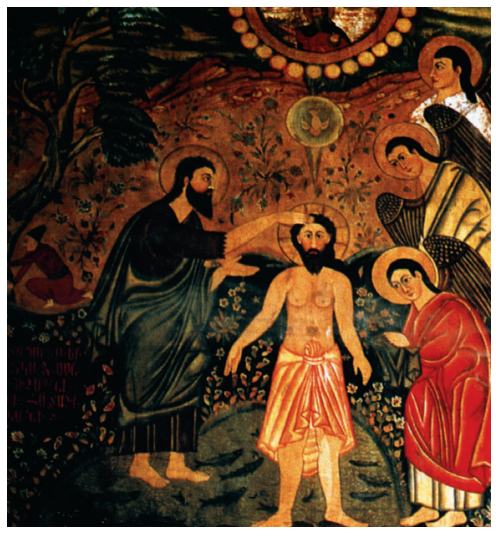

Southern view, 17th century

St. Betlehem Church, New Julfa 
In Isfahan however, the profiles displayed, are primarily of a younger age, with three quarter profiles only, which are expressionless.

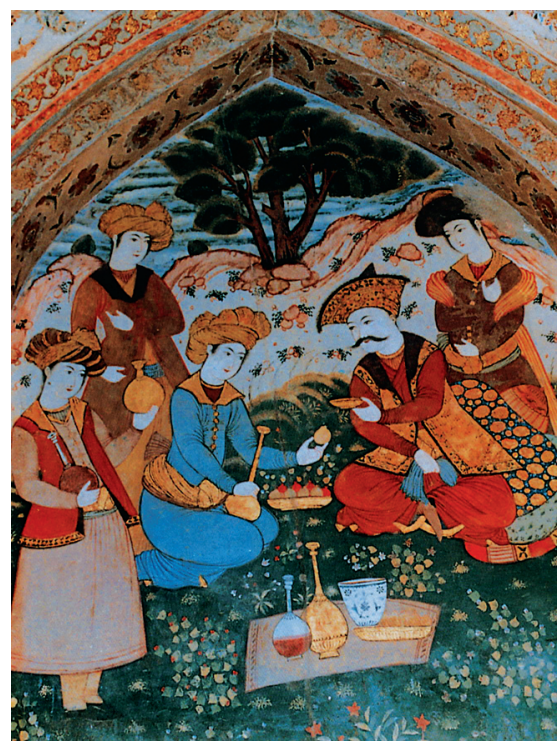

Side Room, western view, 17th century

Chehel Sotoun Palace, Isfahan

It is only in oil paintings in Isfahan where the artists have used light and shadow to introduce human expression to the profile. One common theme in both Isfahan and New Julfa mural paintings is the presence of a blue sky and a single tree.

New Julfa mural paintings have Armenian inscriptions that describe the subject matter of the work to the viewer. At times there is a memorial text which identifies a donor. It is likely that these inscriptions have been intended to bear Armenian national identity.

In the $17^{\text {th }}$ century murals there is no evidence of complete and direct copy from European or other external sources. The elements of external influences are very skillfully combined with the Armenian aesthetic values and reflect the artists' individual intentions and cultural ideals.

In the $17^{\text {th }}$ century both Isfahan and New Julfa mural paintings thus stepped from the Middle Ages to a New Era. This era is the result of a fusion of the art styles of the Middle Ages and the European Renaissance. 


\section{Referances:}

1. Davrijetsi, A. (1990) History, Yerevan: H.Kh.S.H. GA hrat. (in Armenian)

2. Ghazarian, M. (1974) History of Armenian Visual Art in the 17th-18th centuries. Yerevan: Haypethrat. (in Armenian)

3. Ter Hovhanian, H. (1880) History of New Julfa (Isfahan). Isfahan. St. Amenaprkich vanq. (translated from grabar to ashkharabar by Kahana Poghos Petrosian in 1980)

4. Pakbaz, Rooin (2002) Iranian Painting from Ancient Period to the Present, Tehran: Zarin \& Simin. (in Persian)

5. Honarfar, Lotfollah (1971) Historical Treasures of Isfahan. Tehran: Ziba. (in Persian)

6. Carswell, J. (1968) New Julfa, The Armenian Churches and Other Buildings. Oxford: Clarendon.

7. Der Nersessian, S.; Mekhitarian, A. (1986) Armenian Minatures from Isfahan. Brussels: Les Editeurs d'Art Associes, Armenian Catholicosate of Cilicia.

8. Hakhnazarian, A. (1992) New Julfa. Italy: Documents of Armenian Architecture.

9. Taylor, Alice (1996) Book Arts of Isfahan. Arizona: Arizona Litographers. 